\title{
Currency regime crises, real wages, functional income distribution and production ${ }^{*}$
}

\author{
Emiliano Brancaccio \\ University of Sannio, Italy \\ Nadia Garbellini \\ University of Bergamo, Italy
}

\begin{abstract}
This study examines 28 selected cases of transition from a fixed to a more flexible exchange rate combined with devaluation over the period 1980-2013. The crises examined generally prove to be significantly correlated to a reduction in real wages and the wage share. However, both groups are also characterised by an important degree of variability with respect to sample averages, which suggests that the dynamics of real wages and wage shares were also influenced by the specific institutional and political environments in which such crises and devaluations took place. Finally, there appear to be no adequate empirical grounds for the claim that a decrease in real wages resulting from a currency regime crisis will result in improved levels of production and employment. All evaluations of the links between the currency regime and the dynamics of wages and distribution should in any case be carried out not in abstract terms but by comparing the possible implications of abandoning the regime with those of maintaining it. The opportunity of a comparative analysis also applies to the study of current episodes, such as the eurozone crisis.
\end{abstract}

Keywords: currency regime crisis, euro, real wages, wage share

JEL codes: E24, E25, F30, F4O

\section{INTRODUCTION}

The prolongation of the crisis of the European Monetary Union rekindles doubt as to its future sustainability and arouses interest in the implications of its possible collapse. ${ }^{1}$ In this connection, the representatives of the major EU institutions have expressed concern about the perils that would ensue from abandonment of the single currency, insisting among other things that countries leaving the eurozone and devaluing the currency create high inflation (Draghi 2011). Consideration of this possibility raises several questions, one of which concerns the effects that such a decision would have on real wages and the functional distribution of income. An influential view in this regard is that a currency regime crisis combined

* The authors would like to thank three anonymous referees for their valuable comments on previous drafts of this paper. The usual disclaimer applies.

1. For the problems of the sustainability of the eurozone in its present form and the existence of a choice of alternative ways out of the EU, see the 'economists' warning' published in the Financial Times and signed by a whole range of leading figures in the international academic community (Brancaccio et al. 2013).

Received 3 February 2014, accepted 24 October 2014 
with devaluation triggers an increase in the price of imports and therefore - at least in the short term - a decrease in the purchasing power of wages, which, if particularly accentuated, can lead to riots and strikes against the higher prices of foreign goods (Blanchard 2000; Blanchard et al. 2013). Above and beyond the social implications, the problem is to ascertain whether the claim that devaluation has a negative effect on the purchasing power of wages and the distribution of incomes can be considered generally valid. One way to do this is to examine the corresponding effects of past episodes of currency regime crisis combined with devaluation. This study examines cases of transition from a comparatively rigid to a more flexible exchange-rate regime combined with devaluation taking place between 1980 and 2013 so as to analyse the possible repercussions on real wages and the wage share. Section 2 examines the relevant literature. Section 3 outlines the methodology adopted for selection of the sample, dataset and sources. Section 4 presents some descriptive statistics. Section 5 carries out some regression tests on the data sample selected. Section 6 seeks to ascertain the existence or otherwise of a link between the dynamics of real wages and the level of production subsequent to crises. Section 7 draws some elements from the analysis on the effects of past crises to set a correct approach to the crises of our time, such as the eurozone crisis. Section 8 draws conclusions.

\section{CURRENCY REGIME CRISES AND DEVALUATION: AN OVERVIEW OF THE EFFECTS ON REAL WAGES, DISTRIBUTION AND PRODUCTION}

While the literature on the macroeconomic implications of currency regime crises accompanied by devaluation is extraordinarily vast, there are not many studies focusing specifically on the effects of such crises on the purchasing power of wages and the functional distribution of income. With no claim to provide an exhaustive overview, attention will be drawn here solely to analyses of the effects of these crises and associated depreciation on real wages and the wage share as well as the possible repercussions of these specific effects on the dynamics of production and employment.

The relevant studies generally take it as their starting point that devaluation causes an increase in the price of imported goods and the general price index, and should therefore, without an equal increase in monetary wages, involve at least a temporary drop in real wages. There appears, however, to be no broad agreement on the importance of this phenomenon. Immediately after Britain's abandonment of the gold standard, Keynes stated that the devaluation of sterling would prove advantageous to the country's economy without having any serious impact on the cost of living and the purchasing power of wages because imports accounted for less than a quarter of national consumption (Keynes 1931). In 1944, however, he asserted that devaluation improves the balance of payments only if wages are not linked to prices and therefore at the cost of marked deterioration in workers' living standards (Keynes 1980: 288). Kaldor also maintained initially that gradual depreciation would have tolerable repercussions on real wages (Kaldor 1965 [1978]) but later asserted that countries with a balance-of-payments deficit can only remedy this situation through massive devaluation, which would have severe repercussions on the purchasing power of wages; it was also for this reason that he concluded that the lever of devaluation should be replaced with a policy of control over imports (Kaldor 1978). It appears difficult to draw definitive conclusions on the question also from the most recent empirical research, as estimates of pass-through - that is, the impact of devaluation on import prices and the consumer price index in general - give somewhat heterogeneous results. While some devaluations of the 1990s appear to have had a modest impact on prices (Burstein et al. 2007), some authors note a tendency for the pass-through to rise in OECD countries 
(Campa/Goldberg 2006). Moreover, in order to determine the effects of price increases on real wages, it is also necessary to estimate the reaction of monetary wages, and there appears to be no general consensus on this point either.

The positions appear no less diversified in the analyses supported by explicit theoretical models. Some Keynesian contributions give particular prominence to the impact of devaluation on real wages and the wage share. According to Alexander (1952), Dìaz Alejandro (1963) and Krugman/Taylor (1978), currency depreciation increases the price of imported goods and therefore leads - in the case of monetary wages that remain rigid or adapt only partially and after some delay - to a drop in real wages and a shift in the distribution of income from the wage share to the profit share. These results are confirmed by more recent post-Keynesian analyses, where the estimated magnitude of the effect of devaluation on wages and distribution depends on the import dependency of the economy, the ability of firms to reflect import price changes to consumers and the inability of workers to index wages to inflation (Onaran 2009). Other lines of research, however, leave various possibilities open on the view that the wage-negotiation system will determine whether devaluation has repercussions on real wages (Sachs 1980; Willmann 1988). ${ }^{2}$ Furthermore, there are also studies that rule out any impact on real wages. The overshooting model, to give one celebrated example, examines the effects of devaluation on the assumption that the relationship between monetary wages and monetary prices remains constant also in the presence of variations in production (Dornbusch 1976). No clear-cut conclusions can be drawn even in the sphere of the more recent models developed for currency regime crises. According to the so-called 'first generation' models, such crises and the associated devaluation have no effect on the real variables, therefore including real wages and the functional distribution of income (Krugman 1979; Flood/Garber 1984), whereas some later models state that devaluation can reduce real wages and the wage share in the short term (Eichengreen et al. 1994; for an overview, see Jeanne 1999 and Burnside et al. 2007).

As regards the possibility of the effects of devaluation on wages and distribution having repercussions on the levels of production and employment, a useful distinction can be drawn between Keynesian models and neoclassical mainstream models (for the definition of 'mainstream', see Brancaccio 2011). While the latter concentrate on the supply side and posit a 'natural' equilibrium ultimately determined by the available stocks of productive resources as well as the preferences of economic agents and existing technology, the former criticise the concept of 'natural equilibrium' and establish a link between the variables on the demand side. ${ }^{3}$ The group of Keynesian models includes the above-mentioned contributions of Alexander (1952), Dìaz Alejandro (1963) and Krugman/Taylor (1978), which argue that the propensity to consume is higher for wages than for profits and therefore that the effect of devaluation on distribution can cause a possible lasting reduction also of aggregate demand and production. Recent studies have shown that in some cases this contraction can outweigh the expansion expected to result from the greater competitiveness of national goods (Hein/ Vogel 2008). Among the studies belonging to the group of mainstream analyses, attention should be drawn to the models of currency regime crises that assume in one way or another

2. On the relationships between wage bargaining, exchange rates and real wages, see also Cavallari (2001) and Cuciniello (2011).

3. In the mainstream analyses, the more or less implicit reference to a 'natural' equilibrium determined by 'fundamentals' also underlies considerations of a normative character such as the distinction between 'sustainable' or 'coherent' economic policies and 'populistic' or 'incoherent' policies (Dornbusch/Edwards 1989; Bordo/Schwartz 1996). For a criticism of this concept of equilibrium, see Kurz/Salvadori (1995) and Pasinetti (2000), among others. 
the existence of an inverse relation between real wages and levels of employment and production, either through reference to a neoclassical production function or through other particular hypotheses regarding technology or market form. Implicit in the studies that adapt the model of Barro/Gordon (1983) to international analysis (Obstfeld 1996; Castrén et al. 2010), this relation is explicit in the more recent models, where the hypotheses on productive technology are explicitly stated (Weber 1998; Cavallari/Corsetti 2000; Loisel/ Martin 2001; Aghion et al. 2004). It implies, for example, that in a model that assumes the parity of purchasing power and an initial situation of current-account equilibrium, the result of a decision to abandon a fixed exchange rate and hence devalue is an increase in internal prices. If it is assumed that expectations adapt with some delay, the result is a drop in real wages leading to an increase in employment and production. The government will decide to abandon the exchange-rate regime if the associated costs in terms of reputation are offset by the increase in employment. Among other things, this possibility opens the way to multiple equilibria conditioned by expectations (Obstfeld 1996). As regards the distribution of income, in the models that assume that technology is represented by a neoclassical production function and that capital is given, any devaluation that reduces real wages and therefore causes increases in employment and production will also result in a reduction of the wage share. ${ }^{4}$ In short, while devaluation is associated in some Keynesian models with a not necessarily temporary drop in real wages and the wage share and with a corresponding decrease in demand, production and employment, in the mainstream literature the currency regime crisis and ensuing devaluation are generally associated with a temporary fall in real wages and the wage share and with a corresponding increase in employment and production. ${ }^{5}$

Few of the studies focusing primarily on empirical analysis are specifically devoted to the effects of currency regime crises on wages and distribution. Some have examined these crises in terms of the impact on poverty and inequality. A study published by the International Monetary Fund on 65 cases of currency crisis from the 1970s onwards reveals that they are correlated with increases in the Gini coefficient and the human poverty index. It also reveals an increase of 63 per cent in the rate of inflation from one year to the next, which rises to 92 per cent in cases where the crisis is combined with a decrease in product per capita. The study makes no specific reference, however, to wages or functional income distribution (Baldacci et al. 2002). The few contributions that focus on these particular variables include a study by Eichengreen/Sachs (1984) on the consequences of the devaluations of the early 1930s, which argues that variations in the nominal exchange rate can cause the real variables to depart at least temporarily from their levels of 'natural' equilibrium. It is suggested on the basis of regressions that the countries which decided on abandonment of the gold standard and devaluation in the 1930s registered a corresponding decrease in real wages and that the devaluation and associated drop in real wages contributed to better performance in terms of production than countries maintaining the fixed exchange rate. The conclusion arrived at by Fallon/Lucas (2002) in their study of seven currency crises that took place in the 1990s is similar in some respects. The authors show that real wages in the manufacturing sector fell in all the countries examined during

4. Some models appear to display inconsistencies, however, as in the case where technology is described by means of a traditional neoclassical production function, but a constant functional distribution of income is assumed in the determination of effective demand also in the presence of variation in the ratio of capital to labour (Krugman 1999).

5. There are, however, also more unusual theses in the mainstream sphere, such as a model of partial equilibrium according to which devaluation prompts immigrant workers to return to their home countries, which reduces the supply of labour, increases the equilibrium real wage on the labour market and thus reduces the levels of employment and production (Mishra/Spilinbergo 2011). 
the year of the crisis. The scale of the decrease varied greatly from one country to another with a minimum of -2.7 per cent in Malaysia and a maximum of -44 per cent in Indonesia. This study also noted an apparent direct correlation between the size of the drop in real wages and improvement in the levels of employment and production.

In a study focusing on the wage share in 67 cases of currency crisis from 1975 to 1995 and specifically intended to remedy the paucity of research into the impact of such crises on income distribution, Diwan (1999) shows that subsequent to the crisis and the associated devaluation, the wage share underwent no variation in 5 cases, a temporary decrease in 15 cases, and a decrease that lasted for some years in of all the remaining 47 cases. The author suggests that this is because the currency crisis triggers a change in the structure of the power relations between labour and capital but offers no theoretical model in support of this view. A more recent study by Maarek/Orgiazzi (2013) on 82 currency crises in 20 countries starting from the 1980s, focusing exclusively on the manufacturing sector, reveals a drop in the manufacturing wage share in 72 per cent of the cases examined. The decrease is of 2.4 per cent 3 years after the outbreak of the crisis, with a peak of 2.9 per cent between the second and third years. From the fourth year on, however, it appears to converge on its initial level. The authors argue on the basis of an econometric test that the change in distribution cannot be due to changes in the composition of the sectors of production and that a decrease in the wage share instead becomes necessary after a currency crisis in order to keep the return on capital in line with the international level and thus avert the risk of capital flight and a fall in production. The change in distribution can prove temporary if caused by contingent factors such as debts previously contracted in foreign currencies. The authors believe that their results can be interpreted in the light of the theories put forward by Rodrik (1997) and others, according to which the opening of markets is detrimental to labour.

The following indications can therefore be drawn from this brief overview of the relevant literature. From the viewpoint of empirical analysis, currency regime crises combined with devaluation are generally associated with decreases in real wages and the wage share that can also prove severe in some cases. The decrease in wages is usually registered in the year of devaluation and tends to be reabsorbed in the following years. There appears to be little agreement on the duration of the fall in the wage share: lasting at the aggregate level but apparently limited in the manufacturing sector to a period of 3 years after the crisis. The prevailing explanation of these effects on wages and income distribution rests on the idea that monetary wages react only after an interval to the inflation caused by the drop in the exchange rate. Finally, as regards the possibility that devaluation, by acting on real wages and the functional distribution of income, may have repercussions on production levels, the findings diverge according to the type of model adopted, and the relationship between the variables is positive for some and negative for others. The following sections will examine the statistical relations between currency crises and levels of wages and the wage share in greater depth and then go on to examine the possible repercussions on production.

\section{SELECTION OF THE DATA SOURCES AND SAMPLE}

Let us start by specifying the sample of cases examined, which will involve clarifying the meaning of the term 'currency regime crisis'. Various criteria of classification for such crises can be identified in the literature, starting with the IMF de facto classification of exchange-rate regimes adopted since 1970, which ranks exchange-rate arrangements on the basis of their degree of flexibility and the existence of formal or informal commitments to exchange-rate paths undertaken by the economic authorities and especially the central 
bank (Ilzetzki et al. 2008). ${ }^{6}$ Diwan (1999) adopts the definition put forward by Frankel/ Rose (1995), according to which a currency crisis takes place when the nominal exchange rate with respect to the dollar falls by over 25 per cent in a year. Maarek/Orgiazzi (2013) prefer the definition of Kaminsky/Reinhart (1999), which takes into consideration not only devaluation but also variations in currency reserves.

The definition adopted here combines the changes in regime registered by the official IMF classification with the criterion put forward by Frankel/Rose (1995). As a result, the analysis ignores both devaluations involving no change in regime and changes in regime not accompanied by devaluation of at least 25 per cent. Our purpose in this is to define a currency regime crisis in more restrictive terms than those predominantly used in the literature so as to encompass not only the phenomenon of devaluation but also the political and institutional changes that generally characterise the abandonment of an exchange-rate regime. The effect of devaluation on wages and distribution also depends in fact on the institutional commitments undertaken by the economic authorities within the framework of a given regime and on their effect on the dynamics of expectations and negotiations. Our first step was accordingly to select from the IMF classification all the cases of transition from a rigid to a more flexible regime. The second was to narrow the analysis still further by selecting from these cases all those in which the transition from one regime to the other was accompanied by nominal devaluation with respect to the dollar of over 25 per cent in the same year, the previous year or the following year. The 'year of crisis' is defined as the one of those in which such a devaluation took place. The final selection eliminated all the remaining cases for which data on real wages and the wage share were not available, leaving a total of 28 cases concentrated in the period 1981-2003 and relating to 26 different countries.

The data are examined with respect to three groups, namely the entire set of 26 countries considered (ALL) and two subsets, one of seven countries with high per-capita income (HI) and the other of 19 with low per-capita income (LI). This division was made on the basis of the World Bank classification for 2012 with the threshold of US\$20 000 per year, which gives a particularly accentuated gap between the first country above it and the first below. Table 1 gives the complete list of countries and data available. ${ }^{7}$ The databases used are: AMECO, WDI, IFS, CEPALSTAT and UNSD-SNA. The real wage used is the one based on the consumer price index.

\section{DESCRIPTIVE STATISTICS}

In the year of crisis, the mean currency devaluation with respect to the US dollar is 48.83 per cent for the entire sample examined, 29.12 per cent for the high-income countries and 59.44 per cent for the low-income countries. The mean rate of inflation of the consumer price index rises from 10.6 per cent in the previous year to 24.6 per cent in

6. This classification envisions five categories of regime characterised by different kinds of commitment and presented in order from the most rigid to the most flexible (http://www.imf.org/external/np/ $\mathrm{mfd} / \mathrm{er} / 2006 / \mathrm{eng} / 0706 . \mathrm{htm})$.

7. It should be noted that the 1992 devaluation of sterling is not included in the sample examined here and does not in fact appear in the IMF classification. Great Britain is registered as having a freely floating regime from the abandonment of Bretton Woods until 2007 and there is therefore no mention of its joining the European Monetary System in 1990 and pulling out in 1992. The decision not to include these British changes of regime in the IMF classification appears questionable. In any case, even if the criterion of inclusion in the IMF list were waived here, the case would still not be included in the sample because the devaluation of 1992 was far below the threshold value of 25 per cent set by Frankel/Rose (1995) and indeed also below 20 per cent. 
Table 1 Data availability

\begin{tabular}{|c|c|c|c|c|c|c|}
\hline \multirow[t]{2}{*}{ Country } & \multirow[t]{2}{*}{ Year } & \multicolumn{2}{|c|}{ Data availability } & \multirow{2}{*}{$\begin{array}{l}\$_{g, t} \\
(\%)\end{array}$} & \multirow{2}{*}{$\begin{array}{l}\text { Regime } \\
\text { shift }\end{array}$} & \multirow{2}{*}{$\begin{array}{l}\text { Income } \\
\text { level }\end{array}$} \\
\hline & & $\omega_{g}$ & $\omega_{g}^{S}$ & & & \\
\hline Argentina & 2002 & 1997-2007 & 1997-2007 & 206.48 & $1 \rightarrow 3$ & LI \\
\hline Australia & 1985 & 1980-1990 & 1980-1990 & 25.66 & $1 \rightarrow 4$ & HI \\
\hline Belarus & 1999 & 1994-2004 & 1994-2004 & 440.45 & $3 \rightarrow 4$ & LI \\
\hline Brazil & 1999 & 1994-2004 & 1994-2004 & 56.30 & $3 \rightarrow 4$ & LI \\
\hline Chile & 1982 & 1981-1987 & 1977-1987 & 30.53 & $1 \rightarrow 3$ & LI \\
\hline Costa Rica & 1981 & 1981-1986 & 1976-1986 & 153.95 & $1 \rightarrow 3$ & LI \\
\hline Costa Rica & 1991 & 1986-1996 & - & 33.69 & $3 \rightarrow 4$ & LI \\
\hline Egypt & 2003 & 1998-2008 & 1998-2008 & 30.03 & $1 \rightarrow 3$ & LI \\
\hline Finland & 1993 & $1988-1998$ & 1988-1998 & 27.52 & $1 \rightarrow 4$ & HI \\
\hline Guatemala & 1990 & $1985-1995$ & - & 59.29 & $1 \rightarrow 4$ & LI \\
\hline Honduras & 1990 & 1986-1995 & 1985-1995 & 105.60 & $1 \rightarrow 3$ & LI \\
\hline Iceland & 1985 & 1980-1990 & 1980-1990 & 30.96 & $1 \rightarrow 3$ & HI \\
\hline Indonesia & 1998 & 1996-2003 & $1996-2003$ & 244.18 & $3 \rightarrow 4$ & LI \\
\hline Italy & 1993 & 1988-1998 & 1988-1998 & 27.69 & $2 \rightarrow 4$ & $\mathrm{HI}$ \\
\hline Kazakhstan & 1999 & 1994-2004 & 1994-2004 & 52.64 & $3 \rightarrow 4$ & LI \\
\hline Korea, Rep. of & 1998 & $1993-2003$ & $1993-2003$ & 47.32 & $3 \rightarrow 4$ & HI \\
\hline Mexico & 1995 & 1990-2000 & 1990-2000 & 90.20 & $3 \rightarrow 4$ & LI \\
\hline Paraguay & 1989 & 1984-1994 & 1984-1994 & 92.04 & $1 \rightarrow 3$ & LI \\
\hline Peru & 1988 & 1983-1993 & - & 665.22 & $1 \rightarrow 3$ & LI \\
\hline Poland & 1990 & $1985-1995$ & 1986-1995 & 560.10 & $1 \rightarrow 3$ & LI \\
\hline Romania & 1990 & - & 1986-1995 & 50.33 & $1 \rightarrow 3$ & LI \\
\hline South Africa & 1984 & 1979-1989 & 1979-1989 & 32.42 & $3 \rightarrow 4$ & LI \\
\hline Spain & 1983 & $1978-1988$ & 1978-1988 & 30.56 & $3 \rightarrow 4$ & HI \\
\hline Suriname & 1994 & 1991-1998 & 1989-1998 & 12362.79 & $1 \rightarrow 3$ & LI \\
\hline Sweden & 1993 & 1988-1998 & 1988-1998 & 33.65 & $1 \rightarrow 3$ & $\mathrm{HI}$ \\
\hline Turkey & 1999 & 1994-2004 & 1994-2004 & 60.62 & $3 \rightarrow 4$ & LI \\
\hline Uruguay & 1982 & 1981-1987 & 1977-1987 & 28.35 & $3 \rightarrow 4$ & LI \\
\hline Uruguay & 2002 & 1997-2007 & 1997-2006 & 59.60 & $2 \rightarrow 4$ & LI \\
\hline
\end{tabular}

Notes: $\omega_{g}=$ rate of growth of real wage; $\omega_{g}^{S}=$ rate of growth of wage share; $\$_{g}, \mathrm{t}=$ rate of growth of nominal exchange rate ( $t$ refers to the crisis year); $\mathrm{LI}=$ low-income country; $\mathrm{HI}=$ high-income country.

Exchange Rate Regimes Legend: (1) No separate legal tender; Pre-announced peg or currency board arrangement; Pre-announced horizontal band $\leq+/-2 \%$; De facto peg. (2) Pre-announced crawling peg, Pre-announced crawling band $\leq+/-2 \%$; De facto crawling peg; De facto crawling band $\leq+/-2 \%$. (3) Pre-announced crawling band $\geq+/-2 \%$; De facto crawling band $\leq+/-5 \%$; Moving band $\leq+/-2 \%$. (4) Managed floating. (5) Freely floating.

the year of crisis for the sample as a whole, from 4.5 per cent to 6.7 per cent for the highincome countries and from 12.03 per cent to 28.7 per cent for the low-income countries.

With $t$ used to denote the year of crisis, Table 2 presents some descriptive statistics on the trend as regards real wages and the wage share in the 5 years before $t$ and the aggregate rates of percentage variation of the two variables from the year $t$ to the year $t+5$. The trend has been computed, for each country, as the average pre-crisis rate of growth of both the real wage and the wage share. Cumulative rates of growth are computed with respect to period $t+1$.

Observation of the entire sample of countries examined reveals that during the 5 years before the crisis the annual average growth of real wages was 0.9 per cent. Real wages decreased 
Table 2 Descriptive statistics

\begin{tabular}{|c|c|c|c|c|c|c|c|c|c|c|}
\hline & \multicolumn{10}{|c|}{ All countries } \\
\hline & \multicolumn{5}{|c|}{ Rate of growth of real wage $\left(\omega_{g}\right)$} & \multicolumn{5}{|c|}{ Rate of growth of wage share $\left(\omega_{g}^{S}\right)$} \\
\hline & Min. & Median & Mean & Max. & SD & Min. & Median & Mean & Max. & SD \\
\hline Trend & -4.92 & & & & & & & & 3.65 & 2.36 \\
\hline & -29.07 & -2 . & -5 . & 13.9 & 11.80 & -24. & & -2 . & 18.74 & 9.07 \\
\hline+1 & & -3 . & -8 . & 19. & & & & & 7.09 & 7.59 \\
\hline & -63.91 & -1.6 & -3.9 & 53.6 & 22.46 & -17 . & & -5 . & 20.91 & 8.7 \\
\hline & & -0 . & -0.7 & 60.1 & 24. & & -5 & -3. & 25.71 & 11.92 \\
\hline$t+4$ & -59.90 & -0.29 & -1.43 & 64.76 & 24.50 & -26.64 & & -3.93 & 21.69 & 10.97 \\
\hline$t+5$ & -60.21 & 1.20 & -0.69 & 93.94 & 29.14 & -21.08 & -6.33 & -6.50 & 16.08 & 9.94 \\
\hline
\end{tabular}

\begin{tabular}{|c|c|c|c|c|c|c|c|c|c|c|}
\hline & \multicolumn{10}{|c|}{ High-income (HI) countries } \\
\hline & \multicolumn{5}{|c|}{ Rate of growth of real wage $\left(\omega_{g}\right)$} & \multicolumn{5}{|c|}{ Rate of growth of wage share $\left(\omega_{g}^{S}\right)$} \\
\hline & Min. & Median & Mean & Max. & SD & Min. & Median & Mean & Max. & $\mathrm{SD}$ \\
\hline Trend & -4.39 & & & 3.8 & $2 .($ & -2.8 & & -0.54 & 0.36 & 1.07 \\
\hline & -3.42 & -0.8 & -0.34 & 5.6 & $3 .($ & -6.4 & & & 7.2 & 4. \\
\hline$t+1$ & -2.96 & -0.50 & 1.01 & 12.58 & 5.33 & -9.49 & -4.84 & -3.17 & 7.09 & 5.15 \\
\hline+2 & -4.03 & 0. & & 35.55 & 13. & -11. & & -3.50 & 20.91 & 10. \\
\hline$t+3$ & -3.41 & 2.4 & & 38.95 & 14.59 & -11.05 & & -2.99 & 22.20 & 11.44 \\
\hline$t+4$ & & 3.8 & & 25.54 & 9.3 & & & -4 & 12.68 & 8.36 \\
\hline & -3.46 & 6.76 & 7.28 & 23.50 & 9.21 & -15.46 & -6.02 & -5.62 & 11.02 & 8.5 \\
\hline
\end{tabular}

\begin{tabular}{|c|c|c|c|c|c|c|c|c|c|c|}
\hline & \multicolumn{10}{|c|}{ Low-income (LI) countries } \\
\hline & \multicolumn{5}{|c|}{ Rate of growth of real wage $\left(\omega_{g}\right)$} & \multicolumn{5}{|c|}{ Rate of growth of wage share $\left(\omega_{g}^{S}\right)$} \\
\hline & Min. & Median & Mean & Max. & $\mathrm{SD}$ & Min. & Median & Mean & Max. & SD \\
\hline Trend & -4.92 & & 0.79 & 7.66 & 3.73 & -5.08 & -0.63 & -0.69 & 3.65 & 2.92 \\
\hline & -29. & & & 13.94 & 13. & & & & 18.74 & 10.40 \\
\hline 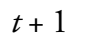 & & & & & & & & & & 7.91 \\
\hline . & & -3 & -7 & 53. & 24. & & & & 7. & 7.90 \\
\hline & & -3 . & & 60. & 26. & & & -4 & 25.71 & 12.40 \\
\hline+4 & -59.90 & -3 . & & 64.76 & 28.1 & -26 & & & 21.69 & 12.03 \\
\hline+5 & -60.21 & -6.58 & & 93.94 & 34.19 & -21.08 & -6.98 & -6.89 & 16.08 & 10.74 \\
\hline
\end{tabular}

on average by 5.18 per cent in the year of crisis $(t)$, continued to fall in the following year and then began to rise again as from $t+2$, almost returning to their initial level $(-0.69$ per cent) 5 years after the crisis. The average annual growth of real wages was 0.79 per cent in the lowincome countries during the years before the crisis, which saw a sharp decrease in $t$ and $t+1$ and a subsequent rise. In this case, however, full recovery was not accomplished, as the average annual growth was negative after the crisis $(-1.05$ per cent) and the accumulated drop in real wages with respect to the pre-crisis level was quite severe 5 years later $(-4.17$ per cent). The situation was different in the high-income countries, where the average annual growth of real wages was 1.11 per cent in the previous years. The year of crisis then saw a slight decrease $(-0.34$ per cent) followed by a period of growth. The annual average growth of wages after the crisis is 1.13 per cent and an accumulated increase of 7.28 per cent is registered at the end of the fifth year with respect to the pre-crisis level. 
As regards the wage share, examination of the entire sample reveals a decreasing trend already prior to the crisis, which is, however, generally associated with a sharper decrease in $t$ and especially in $t+1$ followed by recovery - though in both countries' groups, but especially in low income countries, a significant further drop in the wage share took place, on average, in period $t+5$. In overall terms, the wage share shows an average decrease of 6.5 per cent in $t+5$. While the dynamic is similar in the low-income countries, the highincome group instead shows a modest decrease of -0.67 per cent in the wage share in $t$, more or less in line with the previous trend, followed nearly every year by a sharper fall and an overall decrease of 5.62 per cent with respect to the pre-crisis level in $t+5$.

The standard deviations of the rates of variation of the wage share and real wages show that the sample analysed presents marked heterogeneity, which appears moreover to increase in the years subsequent to devaluation. Among the factors from which such heterogeneity can derive, attention should be drawn to the fact that the crises took place in differing macroeconomic scenarios. While it is true that in the clear majority of cases the change of regime occurred in conjunction with large current account deficits, rises in interest rates and contractions of gross investment, it is also true that in fewer than half of the cases did it occur after negative growth of production had been registered in at least one of the three previous years, there being no fall in real GDP in the other cases. Moreover, the trends of exchange rates subsequent to the crisis prove to be highly differentiated. Above all, in the countries with high per-capita income, devaluation is generally followed by partial revaluation, whereas depreciation usually continues in the following years in the other cases. The dynamics of wage negotiations also prove to differ in the different countries. Suffice it to consider the cases of Italy in 1993 and Argentina in 2002. In Italy, just after the crisis, a new agreement on the cost of labour placed constraints on the growth of wages with respect to prices and productivity (Stirati 2011), whereas the wage policy adopted after the crisis took a different course in Argentina (Neffa 2012). It appears reasonable to suggest that these differences also contributed to the differences in the impact of the crisis on the dynamics of wages and income distribution. Five years after devaluation, Argentina saw growth in real wages and the wage share with respect to the levels registered in the year of crisis (an increase of 36 per cent in real wages and 8.3 per cent in the wage share) while the opposite happened in Italy, where real wages dropped by 3 per cent and the wage share by 6.3 per cent. These data seem to confirm a result reported several times in the literature, especially in the analyses on the effects of structural adjustment programs of the IMF: the impact of currency crises on income distribution changes depending on the type of management policies adopted (Oberdabernig 2013).

\section{CURRENCY REGIME CRISES, REAL WAGES AND THE WAGE SHARE: SOME REGRESSIONS}

The descriptive analysis presented in the previous section indicates first and foremost that the currency regime crises and devaluations examined appear to be effectively associated with an increase in the rates of variation of the consumer price index. This impression is confirmed by the existence of a correlation between variation of the nominal exchange rate with respect to the US dollar and inflation. ${ }^{8}$ This is, however, a heterogeneous

8. Variations in the nominal exchange rate lead to variations in the consumer price index for 29.4 per cent of the sample as a whole as against 31.7 per cent and 29.4 per cent respectively for the high-income and low-income groups. Variations in the nominal exchange rate with respect to the US dollar explain 36.3 per cent of the variability of inflation in the low-income group as against 85.6 per cent in the high-income group. 
phenomenon and one that does not appear to justify talk of 'big inflation' in general terms, especially in the high-income countries characterised by limited devaluation.

The descriptive statistics also reveal marked heterogeneity between the episodes considered as regards real wages and the wage share. With a view to further examination of the effects of currency regime crises on wages and distribution, use can be made of a number of regressions capable of capturing the mean impact of variations in the nominal exchange rate on the magnitudes of interest here, net of the differences between countries. To this end, it was decided to estimate a series of alternative specifications: (i) an ordinary least squares (OLS) model with country-fixed effects and a series of time-dummies, like the one estimated by Maarek/Orgiazzi (2013); (ii) an OLS model with country-fixed effects; (iii) a multi-level model (MLM) with time-random and country-random effects; and (iv) an MLM model with country-random effects. Attention was then focused on the specification that proved capable of explaining the highest percentage of variability, namely (ii). ${ }^{9}$ The equations estimated are as follows:

$$
\begin{gathered}
\omega_{g, i, t}=a_{i}+\sum_{j} \gamma_{j} C r_{t+j}+\beta_{1} \$_{g, t}+\sum_{j} \beta_{1+j} \$_{g, i} C r_{t+j}+\varepsilon_{i, t} \\
\omega_{g, i, t}^{S}=a_{i}+\sum_{j} \delta_{j} C r_{t+j}+\varphi_{1} \$_{g, t}+\sum_{j} \varphi_{1+j} \$_{g, i} C r_{t+j}+\eta_{i, t},
\end{gathered}
$$

where $a_{i}$ are country-fixed effects, $C r_{t+j}(j=0, \ldots, 5)$ crisis dummies that assume a unitary value $j$ years after devaluation takes place, $\phi_{g}$ is the rate of variation of the nominal exchange rate with respect to the dollar, $\omega_{g}$ is the rate of variation of real wages, and $\omega_{g}^{S}$ the rate of variation of the wage share. With respect to the procedure adopted by Maarek/Orgiazzi (2013), our analysis is confined to the objective of establishing whether the crisis coincided with significant change in the dynamics of real wages and the wage share in the cases considered. For this reason, the only explanatory variable included in the equations estimated is the rate of variation of the nominal exchange rate with respect to the US dollar. A second difference is the inclusion of the country-fixed effect alone, whereas time dummies are also used by Maarek/Orgiazzi (2013). In order to limit the number of the regressors - and hence optimise the goodness of fit of the estimates obtained - the models corresponding to equations (1) and (2) were then estimated and the regressors with the highest $p$-value eliminated one by one so as to obtain the highest possible value of the adjusted $R^{2}$. Finally, it was decided to use the rates of variation rather than the levels of the dependent and independent variables. In addition to avoiding some problems connected with the heterogeneity of the data sources used, this approach appears particularly appropriate for the analysis of a dataset characterised by marked disparities in the initial levels of the variables examined. Our analysis instead follows both Diwan (1999) and Maarek/Orgiazzi (2013) in the division of the countries examined into three groups: the entire sample of 26 countries (ALL), the highincome countries (HI) and the low-income countries (LI). Table 3 (on p. 13) shows the results of the estimation of equations (1) and (2).

Before describing the result of the empirical exercise performed, it may be worth devoting a few lines to a methodological proviso. In the analysis developed in the following sections there will be no reference to control groups, because our aim is not that of comparing the countries included in the sample with countries which are not undergoing any crisis. In other words, in this study we will focus on the possible relations between currency regime shifts and the evolution of real wages and income distribution only in countries actually undergoing crisis phenomena. For this scope, our analysis does not

9. The choice of a fixed-effects rather than a random-effects model has been made on the basis of a Hausman test, which fails to reject the null that random-effect coefficients are inconsistent. 
claim to test a general theoretical model of real wage and wage share growth determinants. Rather, it only aims to answer the following questions: (i) In the countries and years included in the sample, is there a correlation between switching to a relatively more flexible exchange-rate regime and a shift in the level of the growth rate of real wages and wage shares? (ii) If so, is there a correlation between the absolute devaluation (that is, the rate of growth of nominal exchange rates) and the extent of such a level shift? (iii) In such a case, is this correlation permanent, or does it undergo significant changes over the 5 years following the regime shift? For this scope, we are going to estimate two systems of equations, one concerning real wages and one concerning wage shares. Question (i) is addressed by means of the introduction, among the regressors, of a set of time (impulse, or seasonal) dummies. Whenever the coefficient associated with a single time dummy is significant, it is legitimate to conclude that in the corresponding time period the average level of the rate of growth of the dependent variable is significantly different from the baseline. Question (ii) is addressed by including, among the 'explanatory' variables, the rate of growth of the nominal exchange rate; if the corresponding coefficient is significant, then it is possible to conclude that a correlation does exist between nominal exchangerate movements and the growth rate of the dependent variable. Moreover, in order to address question (iii), this 'explanatory' variable is made to interact with the abovementioned time dummies. If the coefficient associated with any of these interaction terms is deemed as significant, then it is legitimate to conclude that in the corresponding time period the correlation between the dependent and independent variable is significantly different from the baseline; that is, the coefficient associated with the explanatory variable alone. In the light of this, it is therefore worth pointing out that any time we are going to use the terms 'dependent' or 'explanatory', this is done for the sake of ease of exposition, without attaching to these terms any causal interpretation.

It is necessary to stress that this way of interpreting sample moments of an underlying data-generating process has solid roots in economic literature. As Reiss/Wolak (2007: 4282, emphasis added) point out in the Handbook of Econometrics: '[a]n excellent early example is Engel's (1857) work relating commodity budget shares to total income. ... A somewhat more recent example of descriptive work is the Phillips curve ...'. More recently, this same method has been defined as ' $a$-theoretical by Conway (1991) and applied to a cross-sectional time-series dataset; that is, an unbalanced panel data is the one used in the present contribution, to evaluate the performance of developing countries implementing structural adjustment programs. Conway's report was published by the World Bank and concerns 75 developing countries; each cross-sectional unit includes observations for 11 years. The performance evaluation is based on the correlation between the evolution of the variables chosen as reflecting the economic performance itself and what the author calls 'policy variables'. Such a correlation gives the normal, in the sense of average, reaction and serves as a benchmark for cross-country comparison. The error term gives the systematic response to unobservable incentives and the 'secular economic development trends', and the coefficients associated with country-fixed effects summarise the effect of 'country specific structural factors' (ibid.: 5). In our case, therefore, the economic performance we are interested in is the evolution through time of real wages and wage shares, and the policy variables are the time dummies, indicating when the regime shift took place, and the evolution of the nominal exchange rate. Like Conway, we include in the sample only the countries which underwent such a regime shift and for which the relevant data could be gathered. It is worth stressing once more that the aim of our analysis is not that of comparing the countries included in the sample with countries that are not undergoing any crisis; doing so would require including a control group. In line with what is stated above, our task can be summarized as follows: in countries actually undergoing 
crisis phenomena, which consequences were brought about by the resulting currency devaluation on the evolution of real wages and income distribution?

This procedure has the advantage of not incurring criticisms that have been put forward several times against the application, in order to test theoretical models, of statistical tools whose validity depends on 'convenient assumptions pertaining to stochastic properties of the phenomena which the particular models are intended to explain' (Leontief 1971: 2-3). However, this advantage is also a limitation. Our procedure, in fact, is not intended to apply econometric techniques to test a specific causal hierarchy among the variables based on particular assumptions. Of course, in principle nothing prevents us from verifying the existence of any causal relationship as a further step. In this sense, we can define the procedure described here not so much as an a-theoretical exercise, but rather as a pre-theoretical one.

We can now look at the results of estimating equations (1) and (2). The first three columns of Table 3 refer respectively to the entire sample of countries, the group of high-income countries and the group of low-income countries. They illustrate the impact of the crisis on the variation in real wages. The baseline values given at the end of the table correspond to the average value taken by the dependent variable in the corresponding group of countries in the periods of time for which a time-period dummy is not estimated.

Examination of the sample as a whole reveals that in periods $t$ and $t+1$ the deviation of the growth rate of real wages - given a constant nominal exchange rate - from the baseline proves significant, amounting respectively to negative variations of 5.2 and 3.3 percentage points (p.p.). As regards variations in the exchange rate, their effect is in general - that is, independently of the time period - significant but close to zero: a 1 per cent increase in the nominal exchange rate would reduce the rate of growth of real wage, with respect to the baseline, by 0.002 p.p. (which means 0.05 p.p. in the case of a 25 per cent devaluation). Turning to the interactions with the time dummies, two of these prove significant, namely those taking place in $t+1$, when a 1 per cent increase in the nominal exchange rate would translate into the growth rate of real wages to be 0.016 p.p. lower than the baseline, and in $t+3$, when devaluing by 1 per cent would lead to an increase in the rate of growth of real wages by 0.061 p.p. above the baseline. Similar results are obtained for the low-income countries, where the growth rate of real wages in $t$ and $t+1$ proves significantly lower than the mean by 6.4 and 4.5 p.p. respectively, which correspond net of the baseline to negative rates of change of 5.4 and 3.5 per cent. In the high-income countries, net of variation in the exchange rate, the crisis does not appear in itself to entail significant deviations of the dynamics of real wages from the baseline. The effect of changes in the exchange rate is in this case stronger: a 1 per cent devaluation would reduce the growth of real wages by 0.162 p.p. below the baseline, independently of the period considered with respect to the crisis. The independent variables considered are capable of explaining 38.2 per cent of the variability of the effective mean trend of real wages in the case of the high-income countries and 26.7 per cent in the case of the low-income countries. Though strongly connected with the exchange rate, the variation in the purchasing power of wages depends to a considerable degree on a series of other factors, whose influence proves greater for the low-income countries.

The last three columns of Table 3 respectively show the results for the rate of variation of the wage share for all the countries, the high-income countries and the low-income countries. For the entire sample, in $t+1$ the growth rate of the wage share proves significantly lower than the baseline by 2.8 p.p., which means negative growth of the wage share of over 3 per cent net of the baseline. In $t+3$ the wage share is instead 3.7 p.p. above the mean. The effect of variations in the nominal exchange rate is generally significant. In the low-income countries, the growth rate of the wage share is 4.9 p.p. below the mean in $t+1$ but above it to 
Table 3 Results of estimating equations (1) and (2)

\begin{tabular}{|c|c|c|c|c|c|c|}
\hline & \multicolumn{6}{|c|}{ Dependent variable: } \\
\hline & \multicolumn{3}{|c|}{$\omega_{g}$} & \multicolumn{3}{|c|}{$\omega_{g}^{S}$} \\
\hline & $\begin{array}{l}\text { (All) } \\
(1)\end{array}$ & $\begin{array}{c}(\mathrm{HI}) \\
(2)\end{array}$ & $\begin{array}{l}(\mathrm{LI}) \\
(3)\end{array}$ & $\begin{array}{l}\text { (All) } \\
(4)\end{array}$ & $\begin{array}{c}(\mathrm{HI}) \\
(5)\end{array}$ & $\begin{array}{l}(\mathrm{LI}) \\
(6)\end{array}$ \\
\hline$t$ & $\begin{array}{l}-0.052^{* * *} \\
(0.019)\end{array}$ & & $\begin{array}{c}-0.064^{* *} \\
(0.027)\end{array}$ & $\begin{array}{c}-0.028^{*} \\
(0.015)\end{array}$ & $\begin{array}{c}-0.032^{* * *} \\
(0.011)\end{array}$ & $\begin{array}{c}-0.020 \\
(0.018)\end{array}$ \\
\hline$t+1$ & $\begin{array}{c}-0.033^{*} \\
(0.020)\end{array}$ & $\begin{array}{c}-0.015 \\
(0.013)\end{array}$ & $\begin{array}{c}-0.045^{*} \\
(0.027)\end{array}$ & $\begin{array}{c}0.019 \\
(0.013)\end{array}$ & $\begin{array}{c}-0.016 \\
(0.011)\end{array}$ & $\begin{array}{l}-0.049^{* * *} \\
(0.018)\end{array}$ \\
\hline$t+2$ & $\begin{array}{l}0.038^{* *} \\
(0.019)\end{array}$ & & $\begin{array}{c}0.049^{*} \\
(0.026)\end{array}$ & $\begin{array}{l}0.037^{* *} \\
(0.014)\end{array}$ & & $\begin{array}{c}0.024 \\
(0.018)\end{array}$ \\
\hline$t+3$ & & & & & & $\begin{array}{l}0.049^{* *} \\
(0.021)\end{array}$ \\
\hline$t+4$ & $\begin{array}{c}-0.021 \\
(0.019)\end{array}$ & & & & & \\
\hline$t+5$ & & $\begin{array}{c}-0.017 \\
(0.013)\end{array}$ & & & $\begin{array}{c}-0.014 \\
(0.011)\end{array}$ & \\
\hline$\$ g$ & $\begin{array}{l}-0.002^{* * *} \\
(0.001)\end{array}$ & $\begin{array}{c}-0.162^{* * *} \\
(0.027)\end{array}$ & $\begin{array}{c}-0.002^{* * *} \\
(0.001)\end{array}$ & $\begin{array}{c}-0.008^{* *} \\
(0.004)\end{array}$ & $\begin{array}{c}-0.103^{* * *} \\
(0.023)\end{array}$ & $\begin{array}{c}-0.008^{*} \\
(0.004)\end{array}$ \\
\hline$\$_{g} t$ & & $\begin{array}{c}0.068 \\
(0.045)\end{array}$ & & $\begin{array}{c}0.005 \\
(0.004)\end{array}$ & $\begin{array}{c}0.069^{*} \\
(0.038)\end{array}$ & $\begin{array}{c}0.006 \\
(0.004)\end{array}$ \\
\hline$\$_{g} t+1$ & $\begin{array}{l}-0.016^{* * *} \\
(0.005)\end{array}$ & & $\begin{array}{c}-0.015^{* * *} \\
(0.006)\end{array}$ & $\begin{array}{c}-0.026 \\
(0.018)\end{array}$ & & \\
\hline $\begin{array}{l}\$_{g} t+2 \\
\$_{g} t+3\end{array}$ & $\begin{array}{c}0.061^{* *} \\
(0.029)\end{array}$ & $\begin{array}{c}0.141 \\
(0.120)\end{array}$ & $\begin{array}{c}0.062^{*} \\
(0.033)\end{array}$ & $\begin{array}{c}-0.072^{*} \\
(0.037)\end{array}$ & $\begin{array}{c}0.140 \\
(0.101)\end{array}$ & $\begin{array}{c}-0.093^{* *} \\
(0.045)\end{array}$ \\
\hline$\$_{g} t+4$ & & $\begin{array}{c}-0.139 \\
(0.084)\end{array}$ & & & $\begin{array}{c}-0.147^{* *} \\
(0.071)\end{array}$ & \\
\hline$\$_{g} t+5$ & & & & & & \\
\hline Baseline & 0.013 & 0.012 & 0.010 & -0.005 & -0.005 & -0.000 \\
\hline Obs. & 254 & 77 & 177 & 265 & 77 & 188 \\
\hline & 0.346 & 0.486 & 0.363 & 0.209 & 0.381 & 0.227 \\
\hline Adj. $R^{2}$ & 0.255 & 0.382 & 0.267 & 0.104 & 0.243 & 0.113 \\
\hline
\end{tabular}

Notes: ${ }^{*} p<0.1 ;{ }^{* *} p<0.05 ;{ }^{* * *} p<0.01 ; t+j$ in the table refers to $C r_{j}$ in equations (1) and (2); $\$_{g} t+j$ in the table refers to $\$_{g} C r_{j}$ in equations (1) and (2); $\omega_{g}=$ rate of growth of real wage; $\omega_{g}{ }^{S}=$ rate of growth of wage share; $\$_{g, t}=$ rate of growth of nominal exchange rate ( $t$ refers to the crisis year); $\mathrm{LI}=$ low-income; $\mathrm{HI}$ = high-income.

precisely the same extent in $t+3$. The impact of the crisis appears to be still greater in the high-income countries, where the growth rate of the wage share, already slightly negative on average, drops significantly by another 3.2 p.p. in $t+1$. As regards the impact of the variation in the exchange rate, a 1 per cent devaluation generally translates into a drop of the wage rate by 0.103 p.p.. The independent variables considered here explain 24.3 per cent of the variability of the wage share in the case of the high-income countries but only 11.3 per cent for the low-income countries. Logically enough, the wage share proves more sensitive than real wages to factors other than variations in the nominal exchange rate alone.

Table 4 gives an idea of the possible effect of estimated variations on the absolute levels of real wages and the wage share compared to the pre-crisis trend. Once again, the groups considered are the entire sample of countries examined, the low-income countries and the high-income countries. The annual median depreciation was calculated for each group of 
Table 4 Dynamics of real wage rate and wage share: trend and estimated values

\begin{tabular}{|c|c|c|c|c|c|c|c|c|c|}
\hline & \multicolumn{9}{|c|}{ Real wage rate $(\omega)$} \\
\hline & \multicolumn{3}{|c|}{ All countries } & \multicolumn{3}{|c|}{ High-income (HI) } & \multicolumn{3}{|c|}{ Low-income (LI) } \\
\hline & Est. & Trend & Diff. & Est. & Trend & Diff. & Est. & Trend & Diff. \\
\hline & 100.00 & 100.00 & & 100.00 & 100.00 & & 100.00 & 100.00 & \\
\hline$t$ & 94.98 & 100.89 & -5.91 & 96.03 & 101.11 & -5.08 & 93.13 & 100.79 & -7.65 \\
\hline$t+1$ & 91.22 & 101.80 & -10.58 & 97.33 & 102.24 & -4.91 & 87.56 & 101.58 & -14.02 \\
\hline$t+2$ & 95.38 & 102.71 & -7.33 & 99.23 & 103.38 & -4.15 & 92.10 & 102.38 & -10.28 \\
\hline$t+3$ & 98.18 & 103.63 & -5.45 & 100.62 & 104.53 & -3.91 & 95.08 & 103.18 & -8.10 \\
\hline$t+4$ & 99.42 & 104.56 & -5.13 & 100.57 & 105.69 & -5.12 & 96.00 & 103.99 & -7.99 \\
\hline \multirow[t]{4}{*}{$t+5$} & 100.69 & 105.49 & -4.80 & 101.73 & 106.87 & -5.13 & 96.93 & 104.81 & -7.88 \\
\hline & \multicolumn{9}{|c|}{ Wage share $\left(\omega^{S}\right)$} \\
\hline & \multicolumn{3}{|c|}{ All countries } & \multicolumn{3}{|c|}{ High-income (HI) } & \multicolumn{3}{|c|}{ Low-income (LI) } \\
\hline & Est. & Trend & Diff. & Est. & Trend & Diff. & Est. & Trend & Diff. \\
\hline & 47.92 & 47.92 & & 62.90 & 62.90 & & 39.86 & 39.86 & \\
\hline$t$ & 45.54 & 47.62 & -2.07 & 61.91 & 62.56 & -0.65 & 37.52 & 39.60 & -2.09 \\
\hline$t+1$ & 43.64 & 47.31 & -3.67 & 59.68 & 62.22 & -2.54 & 35.24 & 39.35 & -4.11 \\
\hline$t+2$ & 42.48 & 47.01 & -4.53 & 59.66 & 61.88 & -2.22 & 34.22 & 39.10 & -4.88 \\
\hline$t+3$ & 42.90 & 46.71 & -3.81 & 59.44 & 61.54 & -2.10 & 34.61 & 38.85 & -4.24 \\
\hline$t+4$ & 42.63 & 46.41 & -3.78 & 58.00 & 61.21 & -3.21 & 34.56 & 38.60 & -4.04 \\
\hline$t+5$ & 42.38 & 46.12 & -3.73 & 57.70 & 60.88 & -3.18 & 34.52 & 38.36 & -3.83 \\
\hline
\end{tabular}

Notes: Est. $=$ estimated values; Diff. $=$ difference between estimated values and Trend.

countries examined taking $t-1$ as the base year and assuming that in every period the variation of the nominal exchange rate corresponds to the mean of the effective variations of each country. The annual levels of real wages and the wage share subsequent to devaluation were determined on this basis and recorded in the Estimated columns. These levels were then compared with the Trend columns, which describe the mean trends prior to the crisis.

For the entire sample of countries examined, real wages show a drop of 5 p.p. in $t$ (94.98) and nearly 9 p.p. in $t+1$ (91.22), but then begin to recover and return to the pre-crisis level in $t+5$ (100.69). This level proves, however, to be 4.8 per cent lower than the level corresponding to the pre-crisis trend. In the case of the low-income countries, the overall reduction of real wages between $t$ and $t+5$ amounts to 3.07 per cent, concentrated above all in $t$ and $t+1$, and the difference with respect to the pre-crisis trend is 7.88 per cent. As regards the high-income countries, it is necessary to take into account the fact that in some cases devaluation is followed by partial revaluation. As a result, while real wages fall by nearly 4 per cent in $t$, they then recover and show an overall increase of 1.73 per cent in $t+5$. The level is, however, 5.13 per cent lower with respect to the pre-crisis trend.

With the mean level prior to the crisis taken as the term of comparison, the wage share shows a drop of 5.54 per cent and a decrease of 3.73 per cent with respect to the pre-crisis trend in $t+5$ for the entire sample as against corresponding figures of 5.34 and 3.83 per cent for the low-income countries and 5.2 and 3.18 per cent for the high-income countries.

The following conclusions can be drawn from the results obtained in Table 4. Net of factors other than the explanatory variables considered, the variations in the exchange rate subsequent to currency regime crises are associated with statistically significant reductions 
both of real wages and of the wage share in the high-income and low-income countries alike. For the entire sample, real wages initially decrease but then return to the pre-crisis levels in the space of 5 years. The recovery is stronger in the high-income countries, probably also as a result of the fact that the initial devaluation is followed by partial revaluation in some cases. Real wages instead remain significantly below the pre-crisis level in the lowincome countries 5 years later. In all the groups of countries examined, the wage share falls after the crisis and is still below the level of the pre-crisis trend 5 years later. Finally, and again in all the groups, both real wages and the wage share remain below the levels of the pre-crisis trend 5 years later.

The results obtained are substantially confirmed also when the cases of crisis are selected on the basis of a threshold value of devaluation of 20 per cent rather than 25 per cent. ${ }^{10}$ The inclusion of the ratio of imports to GDP among the explanatory variables of the rates of variation of real wages and the wage share proves statistically insignificant.

\section{ON THE CONNECTION BETWEEN DEVALUATION, REAL WAGES AND PRODUCTION}

As noted above, a currency regime crisis is generally associated in the literature with a decrease in real wages. As we have seen before, however, there is disagreement as regards the impact of the latter on production and employment. While some Keynesian models suggest the possibility of the drop in wages causing a decrease in aggregate demand and production, it instead prompts firms to increase their workforce and production according to the major mainstream analyses of currency regime crises. The theoretical justification of this inverse relation is drawn from the hypotheses on technology, usually represented by a neoclassical function production. This seems also to be the theoretical basis of the observations of Eichengreen/Sachs (1984) and Fallon/Lucas (2002) on currency crises taking place respectively in the 1930s and the 1990s. It may prove useful for our purposes to ascertain the relationship between variations in real wages and variations in production that emerges from the sample of cases examined here. With $Y_{g}$ denoting the growth rate of real GDP, let us examine the following equations:

$$
\begin{gathered}
\omega_{g, i, t}=a_{i}+c_{1} \omega_{g, i, t-1}+c_{2} Y_{g, i, t}+c_{3} Y_{g, i, t-1}+\varepsilon_{i, t} \\
Y_{g, i, t}=a_{i}+d_{1} Y_{g, i, t-1}+d_{2} \omega_{g, i, t}+d_{3} \omega_{g, i, t-1}+\eta_{i, t} .
\end{gathered}
$$

Table 5 presents the results of the estimation of equations (3) and (4), after having performed Wald tests in order to choose the lags to be included. ${ }^{11}$ Even though the sample is too small for any general conclusions to be drawn as regards the causal direction between the two variables, the results can be interpreted as showing that there is no evidence for the existence of a negative correlation between the growth of real wages and the growth of production. On the contrary, the first three columns show that in the cases considered here, variations in the growth rate of real wages are generally accompanied by variations

10. Lowering the threshold to 20 per cent leads to four additions: Colombia 1998, Ecuador 1982, Hungary 1996 and Iceland 2001. Here, too, the operation has been repeated, taking into account the episodes amongst these for which the relevant data are available. (The figures are missing for real wages in Ecuador and real wages and the wage share in Hungary for the years before 1995.).

11. More specifically, the tests performed suggested that, in all three country groups, equation (3) must include the contemporary rate of growth of GDP. By contrast, in equation (4) the growth rate of GDP can be explained by its own lagged value and by the contemporary growth rate of real wages. 
Table 5 Results of estimating equations (3) and (4)

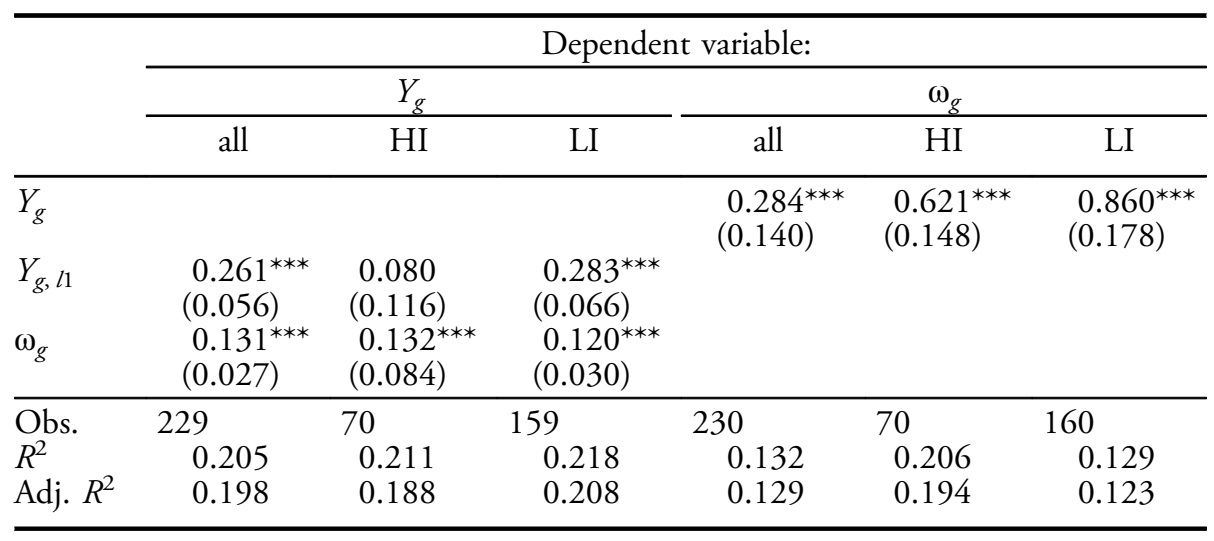

Notes: ${ }^{*} p<0.1 ;{ }^{* *} p<0.05 ;{ }^{* * *} p<0.01$; References: $\omega_{g}=$ rate of growth of real wage; $Y_{g}=$ rate of growth of real GDP; Subscript ' $l 1$ ' refers to the first lag of the corresponding variable.

in real GDP in the same direction. No significant relationship emerges instead between the growth rate of real wages and the dynamics of GDP in the following year. The last three columns show the results for equation (4), which examines the inverse relationship. The correlations both prove significant and again positive. This holds true for all three country groups, the only difference being that the dynamics of the GDP in low-income countries seems to be path dependent, while in high-income countries the lagged growthrate of GDP is uncorrelated with the current one. It is therefore possible to conclude that in the sample considered here there does not emerge any kind of Granger causality between the dynamics of the wage rates and that of the GDP. The two magnitudes are, however, strongly and positively correlated.

It is also possible to repeat the operation carried out by Eichengreen/Sachs (1984: 11) with regard to the evolution of real wages and industrial production in the period 19291935. Expressing both the magnitudes as indices $(1929=100)$, the authors estimate the relationship between their values in 1935, which shows a general decrease with respect to the base year. In order to repeat this on our sample, a regression is estimated with industrial production ${ }^{12}$ as the dependent variable and the index of real wages for the period $t+5$ as the independent variable, both normalised with respect to $t$ as the base year. Figure 1 shows the results, from which a positive rather than negative relation emerges. The operation does not therefore appear to confirm the claim of Eichengreen/Sachs that production improves in cases where the abandonment of an exchange-rate regime and ensuing devaluation are associated with a decrease in real wages. Finally, it should be noted that the use of the level of real GDP or manufacturing value added makes no difference to this result.

\section{FROM PAST TO PRESENT CRISES: SOME REFLECTIONS ON THE EUROZONE TURMOIL}

The sole objective of the analysis developed above is to provide an overall picture of the currency regime crises of the last 30 years and the results are not sufficient to warrant

12. Industrial Production, constant US\$, seasonal adjustments, from the WDI database of the World Bank. 


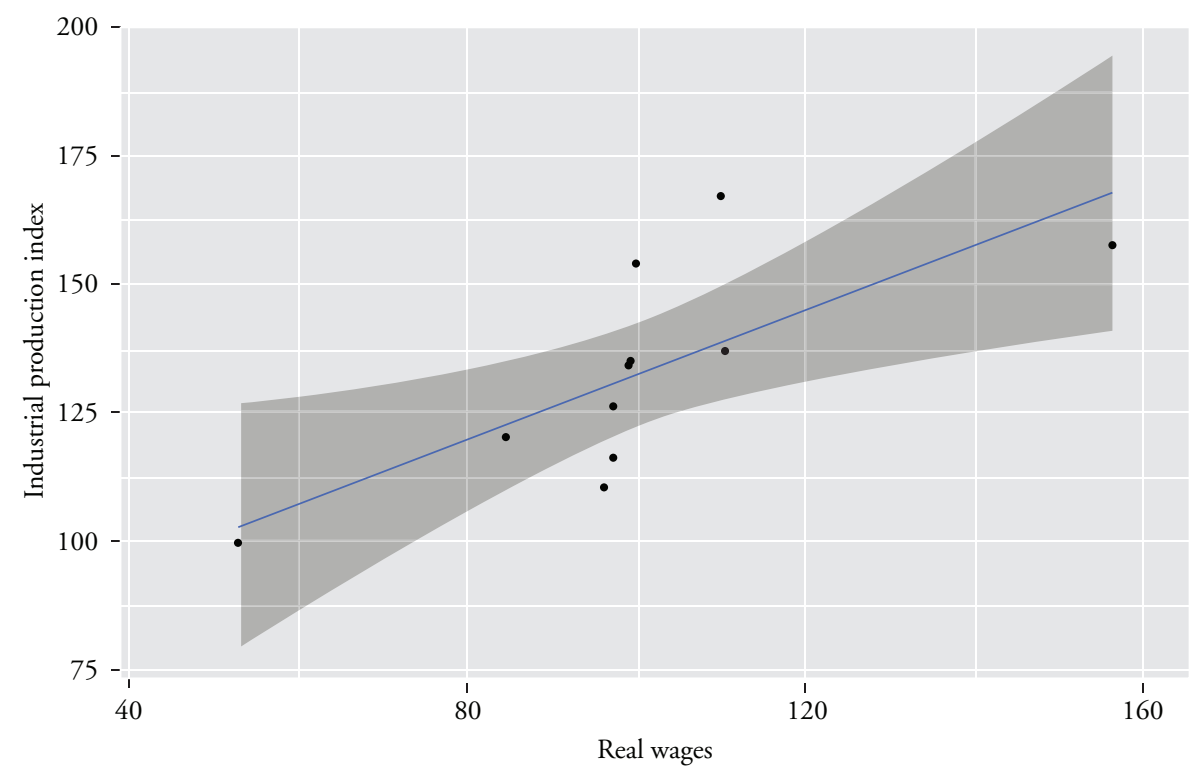

Figure 1 Real wages and industrial production after currency crises

general predictions as to the effects of future crises. It does, however, appear legitimate to draw from them some reflections for a correct approach to current issues such as the crisis in the eurozone. For example, it may prove useful to compare the results of our analysis with the trends in real wages and the wage share that have characterised the eurozone countries from the beginning of the 'Great Recession' (IMF 2012). In this connection, Table 6 presents the data on the dynamics of wages and distribution of the 'peripheral' eurozone countries that have registered particularly high interest rates in the last few years indicative of an increased probability of withdrawal from the single currency and devaluation (see Gros 2011; Brancaccio 2012). The table presents the effective levels of real wages and the wage share in these countries over the period 2009-2013 and compares them with the levels corresponding to the trend of the period 2003-2008 prior to the eurozone crisis.

The data show fairly marked differences in the effective levels between 2009 and 2013 . Mean real wages increased slightly in Ireland, remained almost stationary in Italy and Portugal, decreased in Spain and plummeted in Greece, whereas the wage share instead decreased in all these countries except Italy. With respect to the pre-crisis trends, however, both real wages and the wage share register a drop, which is modest in Italy and Portugal but marked in Spain, Ireland and Greece. It is interesting to note that the decrease in real wages and the wage share registered by these three countries with respect to the pre-crisis trends already proves greater than the one ascertained by the regression in Section 5 for the group of high-income countries 5 years after their respective currency regimes crises. Moreover, the drop in real wages in Greece is greater than that registered for any of the countries examined in the regression, either high-income or low-income. These results indicate that a tendency towards the deflation of real wages has been under way in the eurozone since the beginning of the crisis. This could in a certain sense be regarded as an application of the well-known suggestion that the eurozone's problems of stability 


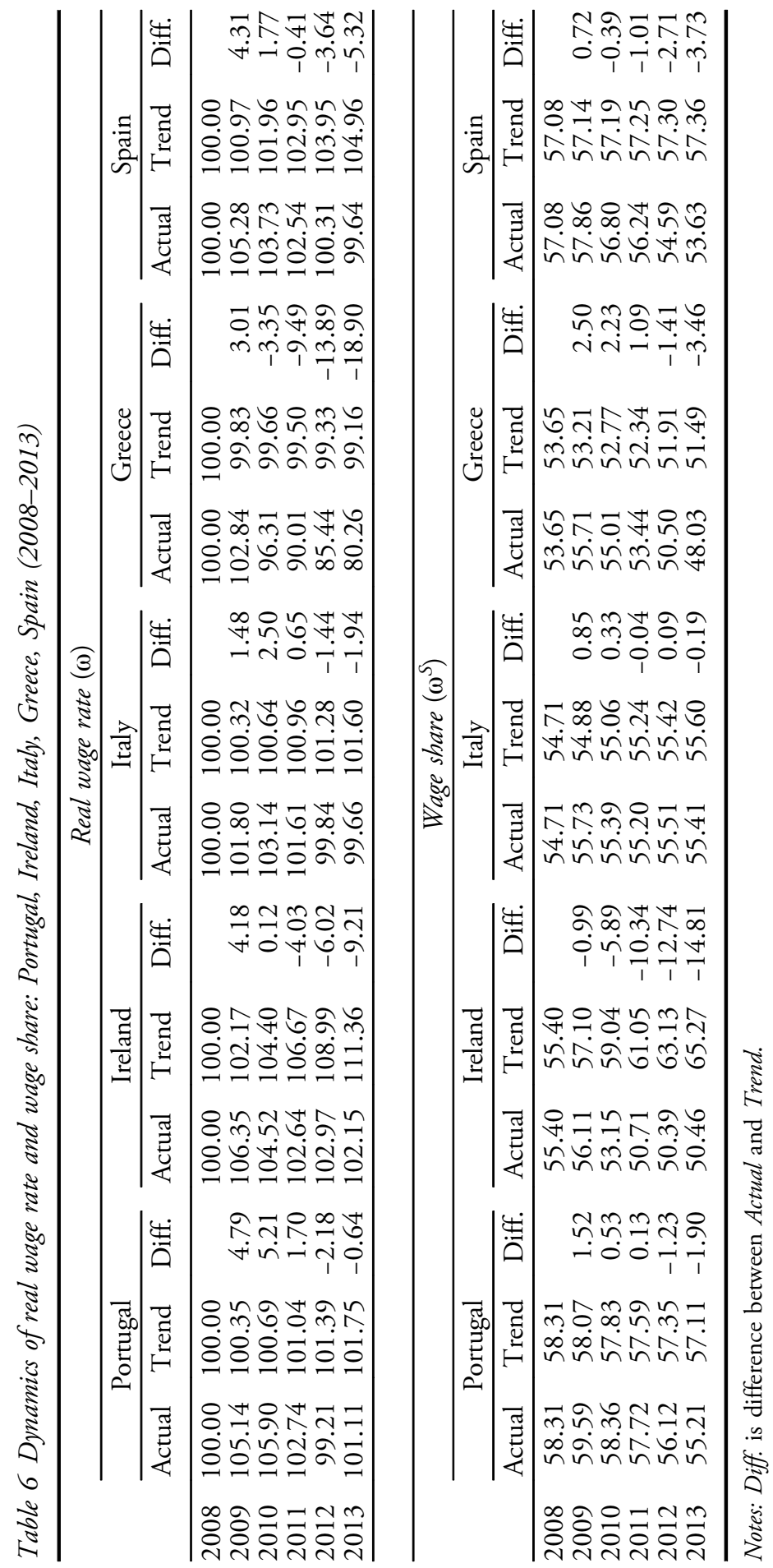


should be addressed through wage deflation, both nominal and real (Blanchard 2007, 2012). This thesis has been criticized by many scholars (Stockhammer 2008; see also Brancaccio et al. 2013, among others), some of whom also provide alternative economic policies for the rebalancing and recovery of the eurozone (Hein 2013; Truger 2013; among others). However, this is not the place to evaluate the weakness of the deflationary view. What matters here is to clarify that if this prescription will maintain its hegemony in the future, it becomes reasonable to expect a continuation of wage deflation within the eurozone. If this is the case, then there would also be obvious consequences on the evaluations about a possible abandonment of the single European currency: especially in a scenario of prolonged deflation, any possible effect of abandonment of the single European currency on wages and income distribution should not be assessed in abstract terms but would rather necessitate comparative examination of the trends in real wages and the wage share already registered since the beginning of the eurozone crisis. Without any claim to provide general conclusions about the much broader issue of overall costs and benefits of monetary union, and quite independently of what one thinks about whether or not to preserve the eurozone, we believe that it is only through comparisons of this type that discussions on this issue can be addressed on analytical grounds.

\section{CONCLUSIONS}

The following conclusions can be drawn from the analysis of the sample considered here. The occurrence of currency regime crises and the associated devaluations are correlated with the reductions of real wages and wage shares. The drop in wages is on average temporary in the high-income countries but persists five years after the crisis in the low-income group, while the decrease in the wage share is persistent in both groups. Five years after the crisis, both real wages and the wage share are lower than the levels obtained by projecting the precrisis trend. The decrease in real wages resulting from the currency regime crises displays no correlation with improved levels of production. However, both groups, and especially the low-income one, are characterised by an important degree of variability with respect to sample averages. This suggests that real wages and wage share dynamics were also influenced by the specific institutional and political environments in which such crises and devaluations did take place, and hence on the different 'exit strategies' implemented. Any evaluation of the relationship between shifts in the currency regime and the dynamics of wages and distribution should in any case be carried out not in abstract terms but by comparing the possible implications of abandoning the regime with those of maintaining it. The necessity of a comparative analysis also applies to the study of current situations, such as the eurozone crisis.

\section{DATA SOURCES}

AMECO Database, Annual macro-economic database of the European Commission's Directorate General for Economic and Financial Affairs, URL: http://ec.europa.eu/economy_finance/indicators/ annual_macro_economic_database/ameco_en.htm (accessed 18 November 2014).

CEPALSTAT, Databases and Statistical Publications, Economic Commission for Latin America and the Caribbean, URL: http://estadisticas.cepal.org/cepalstat/WEB_CEPALSTAT/Portada.asp? idioma $=\mathrm{i}$ (accessed 18 November 2014).

IFS Database, International Monetary Fund, International Financial Statistics, URL: http://elibrary-data. imf.org/finddatareports.aspx?d=33061\&e=169393 (accessed 18 November 2014). 
UNSD-SNA Database, United Nations Statistical Division, System of National Accounts, Main Aggregates and Detailed Tables, URL: http://unstats.un.org/unsd/nationalaccount/sna.asp (accessed 18 November 2014).

WDI Database, World Bank, World Development Indicators, URL: http://data.worldbank.org/ data-catalog/world-development-indicators (accessed 18 November 2014).

\section{REFERENCES}

Aghion, P., Bacchetta, P., Banerjee, A. (2004): A corporate balance-sheet approach to currency crises, in: Journal of Economic Theory, 119(1), 6-30.

Alexander, S. (1952): Effects of a devaluation on a trade balance, in: Staff Papers, International Monetary Fund, 2(2), 263-278.

Baldacci, E., de Mello, L., Inchauste, G. (2002): Financial crises, poverty, and income distribution, IMF Working Paper, 02/4.

Barro, R.J., Gordon, D.B. (1983): A positive theory of monetary policy in a natural rate model, in: Journal of Political Economy, 91(4), 589-610.

Blanchard, O. (2000): Macroeconomics, 2nd edn, Boston: Pearson Education.

Blanchard, O. (2007): Adjustment within the euro: the difficult case of Portugal, in: Portuguese Economic Journal, 6(1), 1-21.

Blanchard, O. (2012): The logic and fairness of Greece's program, iMFdirect, 19 March, URL: http://blog-imfdirect.imf.org/2012/03/19/the-logic-and-fairness-of-greeces-program/ (accessed 20 November 2014).

Blanchard, O., Giavazzi, F., Amighini, A. (2013): Macroeconomics: A European Perspective, 2nd edn, Harlow, UK: Pearson Education.

Bordo, M., Schwartz, A.J. (1996): Why clashes between internal and external stability goals end in currency crises, 1797-1994, National Bureau of Economic Research Working Paper, No. 5710, August.

Brancaccio, E. (2011): Some contradictions in 'mainstream' interpretations of the crisis, in: Brancaccio, E., Fontana, G. (eds), The Global Economic Crisis: New Perspectives on the Critique of Economic Theory and Policy, London: Routledge, 13-26.

Brancaccio, E. (2012): Current account imbalances, the Eurozone crisis and a proposal for a 'European wage standard', in: International Journal of Political Economy, 41(1), 47-65.

Brancaccio, E., Realfonzo, R. et al. (2013): The economists' warning: European governments repeat mistakes of the Treaty of Versailles, in: Financial Times, 23 September, URL: www. theeconomistwarning.com (accessed 20 November 2014).

Burnside, C., Eichenbaum, M., Rebelo, S. (2007): Currency crises models, in: Durlauf, S.N., Blume, L.E. (eds), The New Palgrave: A Dictionary of Economics, 2nd edn, Basingstoke, UK and New York: Palgrave Macmillan, URL: http://www.ssc.wisc.edu/ $\sim$ munia/464/News_ Current/CurrencyCrisis_Palgrave.pdf (accessed 20 November 2014).

Burstein, A., Eichenbaum, M., Rebelo, S. (2007): Modeling exchange rate passthrough after large devaluations, in: Journal of Monetary Economics, 54(2), 346-368.

Campa, J.M., Goldberg, L.S. (2006): Pass through of exchange rates to consumption prices: what has changed and why?, National Bureau of Economic Research Working Paper, No. 12547.

Castrén, O., Takalo, T., Wood, G. (2010): Unemployment persistence and the sustainability of exchange rate pegs, in: Scottish Journal of Political Economy, 57(1), 85-102.

Cavallari, L. (2001): Inflation and openness with non-atomistic wage setters, in: Scottish Journal of Political Economy, 48(2), 210-225.

Cavallari, L., Corsetti, G. (2000): Shadow rates and multiple equilibria in the theory of currency crises, in: Journal of International Economics, 51(2), 275-286.

Conway, P. (1991): An atheoretic evaluation of success in structural adjustment, Country Economics Department, World Bank, Working paper, WPS 629, March.

Cuciniello, V. (2011): The welfare effect of foreign monetary conservatism with nonatomistic wage setters, in: Journal of Money, Credit and Banking, 43(8), 1719-1734. 
Dìaz Alejandro, C.F. (1963): A note on the impact of devaluation and the redistributive effect, in: Journal of Political Economy, 71(6), 577-580.

Diwan, I. (1999): Labor shares and financial crises, Mimeo, Washington, DC: World Bank.

Dornbusch, R. (1976): Expectations and exchange rate dynamics, in: Journal of Political Economy, 84(6), 1161-1176.

Dornbusch, R., Edwards, S. (1989): Macroeconomic populism in Latin America, National Bureau of Economic Research Working Paper, No. 2986, May.

Draghi, M. (2011): FT interview transcript, in: Barber, L., Atkins, R. (eds), Financial Times, 18 December.

Eichengreen, B., Sachs, J. (1984): Exchange rates and economic recovery in the 1930s, National Bureau of Economic Research Working Paper, No. 1498.

Eichengreen, B., Rose, A.K., Wyplosz, C. (1994): Speculative attacks on pegged exchange rates: an empirical exploration with special reference to the European Monetary System, National Bureau of Economic Research Working Paper, No. 4898.

Engel, E. (1857): Die produktions- und consumtionsverhältnisse des königreichs sachsen, in: Zeitschrift des Statistischen Büreaus des Königlich Sächischen Ministeriums des Innern, 8 and 9. (Reprinted in Engel (1895): Appendix I, 1-54.)

Fallon, P.R., Lucas, R.E. (2002): The impact of financial crises on labor markets, household incomes, and poverty: a review of evidence, in: The World Bank Research Observer, 17(1), 21-45.

Flood, R.P., Garber, P.M. (1984): Collapsing exchange-rate regimes: some linear examples, in: Journal of International Economics, 17(1-2), 1-13.

Frankel, J., Rose, A. (1995): Empirical research on nominal exchange rates, in: Grossman, G., Rogoff, K. (eds), Handbook of International Economics, Amsterdam: Elsevier, 1689-1730.

Gros, D. (2011): External versus domestic debt in the euro crisis, CEPS Policy Brief No. 243, 25.

Hein, E. (2013): The crisis of finance-dominated capitalism in the euro area, deficiencies in the economic policy architecture, and deflationary stagnation policies, in: Journal of Post Keynesian Economics, 36(2), 325-354.

Hein, E., Vogel, L. (2008): Distribution and growth reconsidered: empirical results for six OECD countries, in: Cambridge Journal of Economics, 32(3), 479-511.

Ilzetzki, E., Reinhart, C.M., Rogoff, K.S. (2008): Exchange rate arrangements entering the 21 st century: which anchor will hold? Unpublished manuscript and data available online: http://personal.lse.ac. uk/ilzetzki/data.htm (accessed 20 November 2014).

IMF (International Monetary Fund) (2012): World Economic Outlook: Growth Resuming, Dangers Remain, Washington, DC: International Monetary Fund, April, URL: http://www.imf.org/ external/pubs/ft/weo/2012/01/ (accessed 20 November 2014).

Jeanne, O. (1999): Currency crises: a perspective on recent theoretical developments, CEPR Discussion Papers, No. 2170.

Kaldor, N. (1965 [1978]): The relative merits of fixed and floating rates, reprinted in: Kaldor, N., Further Essays on Applied Economics, London: Duckworth, 47-59.

Kaldor, N. (1978): The effects of devaluations on trade in manufactures, in: Kaldor, N., Further Essays on Applied Economics, London: Duckworth, 99-116.

Kaminsky, G.L., Reinhart, C.M. (1999): The twin crises: the causes of banking and balance of payments problems, in: American Economic Review, 89(3), 473-500.

Keynes, J.M. (1931): The end of the gold standard, in: Keynes, J.M., Essays in Persuasion, London: Palgrave Macmillan, 245-249.

Keynes, J.M. (1980): The Collected Writings of John Maynard Keynes, vol. 26, London: Macmillan.

Krugman, P. (1979): A model of balance-of-payments crises, in: Journal of Money, Credit and Banking, 11(3), 311-325.

Krugman, P. (1999): Balance sheets, the transfer problem, and financial crises, in: International Tax and Public Finance, 6(4), 459-472.

Krugman, P., Taylor, L. (1978): Contractionary effects of devaluation, in: Journal of International Economics, 8(3), 445-456.

Kurz, H.D., Salvadori, N. (1995): Theory of Production: A Long-Period Analysis, Cambridge, UK: Cambridge University Press. 
Leontief, V. (1971): Theoretical assumptions and nonobserved facts, in: The American Economic Review, 6(1), 1-7.

Loisel, O., Martin, P. (2001): Coordination, cooperation, contagion and currency crises, in: Journal of International Economics, 53(2), 399-419.

Maarek, P., Orgiazzi, E. (2013): Currency crises and the labour share, in: Economica, 80(319), 566-588.

Mishra, P., Spilimbergo, A. (2011): Exchange rates and wages in an integrated world, in: American Economic Journal: Macroeconomics, 3(4), 53-84.

Neffa, J.C. (2012): La evolución de la relación salarial durante la post convertibilidad, in: Revue de la Régulation, 11, 1er semetre, Spring, URL: http://regulation.revues.org/9695 (accessed 20 November 2014).

Oberdabernig, D.A. (2013): Revisiting the effects of IMF programs on poverty and inequality, in: World Development, 46(C), 113-142.

Obstfeld, M. (1996): Models of currency crises with self-fulfilling features, in: European Economic Review, 40(3-5), 1037-1047.

Onaran, O. (2009): Wage share, globalization and crisis: the case of the manufacturing industry in Korea, Mexico and Turkey, in: International Review of Applied Economics, 23(2), 113-134.

Pasinetti, L. (2000): Critique of the neoclassical theory of growth and distribution, in: BNL Quarterly Review, 215, 383-431.

Reiss, P.C., Wolak, F.A. (2007): Structural econometric modeling: rationales and examples from industrial organization, in: Heckman, J.J., Leamer, E.E. (eds), Handbook of Econometrics, 1st edn, vol. 6A, Amsterdam: North-Holland, ch. 64.

Rodrik, D. (1997): Has Globalization Gone Too Far? Washington, DC: Peterson Institute for International Economics.

Sachs, J. (1980): Wages, flexible exchange rates and macroeconomic policy, in: Quarterly Journal of Economics, 94, 731-747.

Stirati, A. (2011): Changes in functional income distribution in Italy and Europe, in: Brancaccio, E., Fontana, G. (eds), The Global Economic Crisis, London: Routledge, 121-143.

Stockhammer, E. (2008): Wage flexibility or wage coordination? Economic policy implications of the wage-led demand regime in the euro area, in: European Journal of Economics and Economic Policies: Intervention, 5(1), 54-62.

Truger, A. (2013): Austerity in the euro area: the sad state of economic policy in Germany and the EU, in: European Journal of Economics and Economic Policies: Intervention, 10(2), 158-174.

Weber, A. (1998): Sources of currency crises: an empirical analysis, Österreichische Nationalbank, Working Paper, No. 25.

Willman, A. (1988): The collapse of the fixed exchange rate regime with sticky wages and imperfect substitutability between domestic and foreign bonds, in: European Economic Review, 32(9), 1817-1838. 